\title{
Fractal dimension and magnetic susceptibility of magnetically labelled biosorbent based on saccharomyces cerevisiae yeast
}

\author{
S.V.Gorobets, O.Yu.Gorobets, O.V.Kovalyov, \\ A.V.Sopina, Yu.M.Chyzh, S.V.Cherepov \\ National Technical University "Kyiv Polytechnic Institute", \\ 37 Peremohy Ave., 03056 Kyiv, Ukraine
}

Received January 30, 2015

\begin{abstract}
The magnetic susceptibility and fractal dimension of the modified magnetically labelled biosorbent based on Saccharomyces cerevisiae yeast, obtained by magnetohydrodynamic method of mixing the yeast suspension with nano-magnetite particles, were studied. It was established that the surface structure and stability of magnetic susceptibility of magnetically labelled biosorbent change with the change of its fractal dimension.
\end{abstract}

Keywords: magnetically labelled biosorbent, magnetic susceptibility, fractal dimension.

Исследованы магнитная восприимчивость и фрактальная размерность модифицированного магнитоуправляемого биосорбента на основе дрожжей Saccharomyces cerevisiae, полученного магнитогидродинамическим методом перемешивания дрожжевой суспензии с частицами наномагнетита. Исследовано оптимальное время приготовления стабильного магнитоуправляемого биосорбента. Установлено, что при изменении фрактальной размерности магнитоуправляемого биосорбента меняются структура поверхности и стабильность магнитной восприимчивости.

Фрактальна розмірність та магнітна сприйнятливість магнітокерованого біосорбенту на основі дріжджів Saccharomyces cerevisiae. C.В.Горобець, О.Ю.Горобець, О.В.Ковальов, А.В.Сопіна, Чиж Ю.М., С.В.Черепов

Досліджено магнітну сприйнятливість та фрактальну розмірність модифікованого магнітокерованого біосорбенту на основі дріжджів Saccharomyces cerevisiae, отриманого за магнітогідродинамічним методом перемішування дріжджової суспензії з частинками наномагнетиту. Досліджено оптимальний час приготування стабільного магнітокерованого біосорбенту. Встановлено, що при зміні фрактальної розмірності магнітокерованого біосорбенту змінюються структура поверхні та стабільність магнітної сприйнятливості.

\section{Introduction}

The main source of pollution is the sewage of different industries. The intensive development of industry, energy and transport, use of chemicals in agriculture have led to environmental pollution by plenty of chemical and radioactive substances. For this reason, the sewage treatment from pollution of heavy metal ions is an important issue nowadays. A significant threat is the wastewater containing toxic $\mathrm{Cu}^{2+}$ ions, particularly, the effluents of metallurgical and electroplating industries. The modern physico-chemical and chemical methods of sewage treatment from $\mathrm{Cu}^{2+}$ ions do not always provide the necessary degree of their removal, as well as being expensive [1]. The biological methods based on the ability of microorganisms to accumulate or sorb heavy metals ions are of great interest now [2]. 


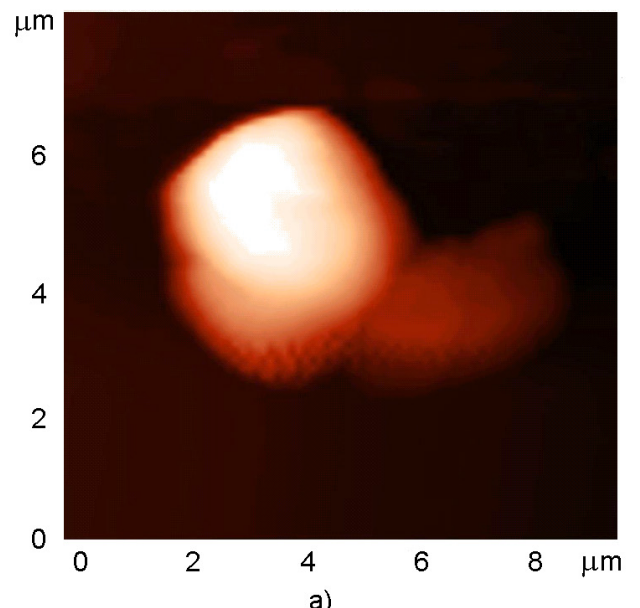

a)

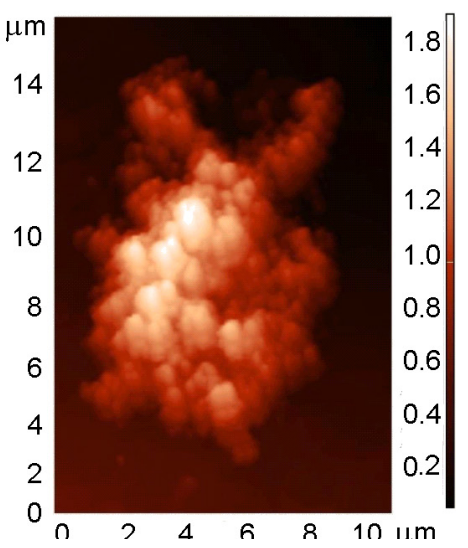

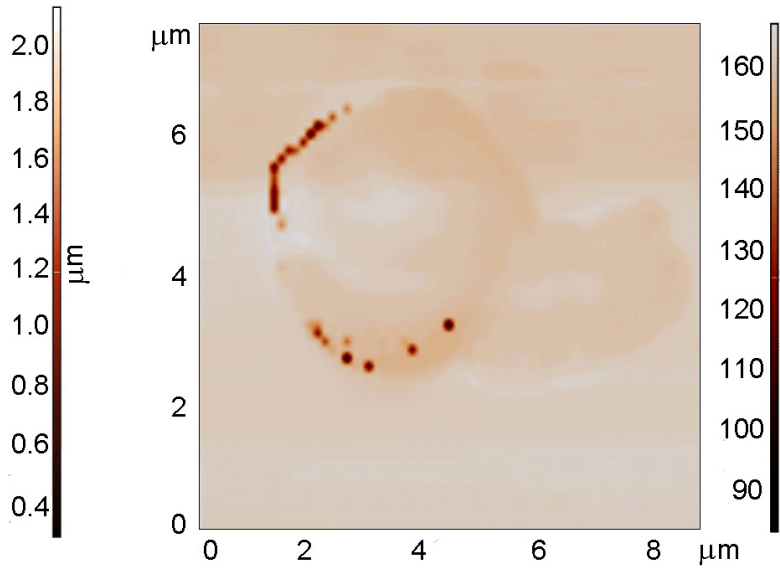

b)

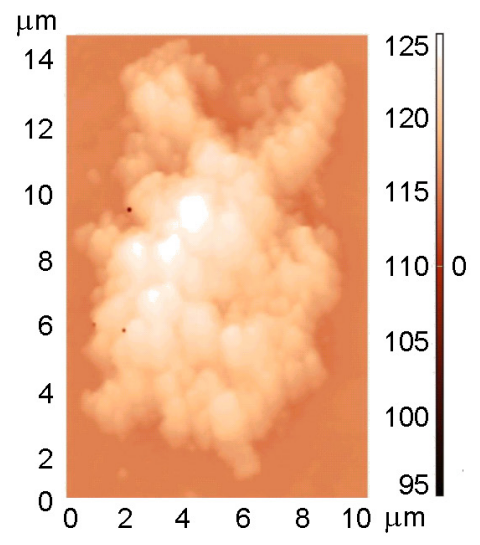

Fig. 1. AFM (a) and MFM (b) images of the biosorbent based on Saccharomyces cerevisiae yeast obtained by mechanical mixing of magnetic nano-labels with yeast cells for 30 min and AFM (c) and MFM (d) images of the biosorbent obtained by multi-vortex MHDM of magnetic nano-labels with yeast cells for $30 \mathrm{~min}$.

The usage of biomass of Saccharomyces cerevisiae yeast as a biosorbent is especially cost-effective. Such a biomass is a secondary product of a number of food productions, which, in its turn, contributes to the solution of the environmental problem of waste disposal [3]. The Saccharomyces cerevisiae yeast have significant potential in the accumulation of a wide range of metal cations, in particular, $\mathrm{Cd}^{2+}, \mathrm{Cr}^{3+}, \mathrm{Cr}^{6+}, \mathrm{Cu}^{2+}$, $\mathrm{Pb}^{2+}$ and $\mathrm{Zn}^{2+}$ ions [4, 5].

The using of magnetically labelled yeast cells for biosorption of heavy metal ions on model solutions has studied for more than twenty years [6,7]. The magnetic nano-labels are used for the obtaining of a magnetically labelled biosorbent with magnetic susceptibility sufficient to effectively remove it of fluid flow with the help of magnetic separators [6,8-10]. The laboratory studies on sorption of $\mathrm{Cu}^{2+}$ ions by magnetically labelled yeast have shown that the sorption capacity of magnetically labelled biosorbent produced using multi-vortex mag- netohydrodynamic mixing (MHDM) is not reduced compared with native yeasts [7, 11].

Using the methods of atomic-force microscopy (AFM) and magnetic force microscopy (MFM) with the help of scanning probe microscope SOLVER PRO-M we found that the morphology of the Saccharomyces cerevisiae cells surface obtained by the method of multi-vortex magnetohydrodynamic mixing (MHDM) differs from the morphology of the cells surface which were produced by the mechanical mixing (Fig. 1). It is known that the fractal dimension circuit cells used to describe different types of cells [12, 13]. In [14] reported a comparison of AFM images of normal and tumor cells, where it is shown that the latter is higher fractal dimension.

The biosorbent obtained by MHDM has more extensive fractal-like surface compared with the sorbent obtained by mechanical mixing. Since the sorption capacity of magnetically labelled biosorbent produced by MHDM is greater than the sorption ca- 
pacity of magnetically labelled native yeast [11], the investigation of such characteristics of the magnetically labeled biosorbent as the sorption capacity of the sorbent, its magnetic susceptibility and the fractal dimension of yeast cell contour is actual. The last two characteristics of the magnetically labeled biosorbent are necessary to develop a proximate method for determining the quality and effectiveness of magnetically labelled biosorbent because the present methods of determining of sorption capacity (the construction of Langmuir isotherms) are quite long-term and require a large number of laboratory experiments.

The fractal dimension is a characteristic of surface morphology that best describes quantitatively the properties of its branching and self-similarity [15]. Fractal-like structures inherent in living systems at all levels of living (corals, starfish and urchins, flowers and plants, fruits, roots and crowns of trees, foliage plants, circulatory system and bronchi in humans and animals, etc.) [15]. In a broad sense the fractal means a figure the small parts of which are similar to itself at an arbitrary increase of this figure. The term "fractal" was introduced by Benoit Mandelbrot in 1975 [16]. It is known that in nature there are no ideal fractals. All biological fractals - quasifraktal.

The surface of the biosorbent obtained by MHDM has a self-similar structure (Fig. 1 c,d). The sorption capacity of a modified biosorbent (MHDM, mixing time from $5 \mathrm{~min}$ to $40 \mathrm{~min}$ ) significantly differs from the sorption capacity of a biosorbent obtained by mechanical mixing [11] (Fig. 1). Consequently, the purpose of the work was to investigate the sorption capacity, the magnetic susceptibility of the magnetically labeled biosorbent and fractal dimension of a sorbent contour at different ways of biosorbent preparation.

\section{Experimental}

\subsection{Method of biosorbent preparation.}

The native biosorbent is obtained by mixing of the Saccharomyces cerevisiae yeast biomass with the concentration of $8 \cdot 10^{9}$ cells/1 with an aqueous solution (the $\mathrm{pH}$ of the solution was adjusted to 2.5 using $\mathrm{HNO}_{3}$ ).

Upon receipt of magnetically labelled biosorbent the yeast biomass was mixed with a solution of nanodimension magnetite in such a way that the volume ratio of biosorbent to nano-magnetite was $100: 1$, the concentration of yeast cells was equal to
$8 \cdot 10^{9}$ cells/1 (100 mg of dry yeast per 1 l), and the concentration of nano-magnetite in the initial solution was $1 \mathrm{mg} / \mathrm{l}$. The resulting solution was adjusted to $\mathrm{pH}=2.5$ by the addition of nitric acid. The multi-vortex MHDM was carried out in the cuvette with steel rods of $0.5 \mathrm{~mm}$ diameter and $30 \mathrm{~mm}$ length. The distance between the rods was $2 \mathrm{~mm}$. The intensity of the external magnetic field was $H=3.5 \mathrm{kOe}$ [11]. At such parameters of the mixing the creation of magnetic nano-labels-yeast cell complexes occurred. The time of mixing was selected in the range from $5 \mathrm{~min}$ to $40 \mathrm{~min}$.

The mechanical mixing during biosorbent preparation was performed by a mixer with frequency of $180 \mathrm{~min}^{-1}$, the $\mathrm{pH}$ of the solution was equal to 5.5 , the mixing time was $5,10,20,30$ and $40 \mathrm{~min}$ [11].

2.2. Research methodology of AFM and MFM images of the yeast cell-nano-label complexes.

The localization of magnetite on the surface of Saccharomyces cerevisiae yeast cells was investigated using AFM and MFM methods by means of a scanning probe microscope SOLVER PRO-M [17]. A doubleline intermittent contact method of a sample study was used in SOLVER PRO-M. During the first pass of the magnetic probe over the surface of the sample (AFM mode), we obtained an AFM surface pattern image. This pattern is remembered, and during the second pass (MFM mode) the phase shift of the cantilever oscillations is measured. This phase shift characterizes the strength of magnetic-dipole interaction of the working area of magnetic probe with magnetite as a part of the studied Saccharomyces cerevisiae yeast cells at the constant distance between the probe and surface of the sample. Magnetite on the cell surface may represent separate nanoparticles and/or their clusters.

2.3.Algorithm for calculating the fractal dimension.

- Download AFM image of yeast cells in bmp format;

- introduce the variables to convert the $\mathrm{X}, \mathrm{Y}$ and $\mathrm{Z}$ Cartesian coordinates of the cell surface to microns;

- create a filter for selection of $2 \mathrm{D}$ curve - cell contour (Fig. 2);

- create a block for calculation of fractal dimension of cell contour which can vary between 1 and 2;

- test the code for the modeling fractal - Koch curve. 

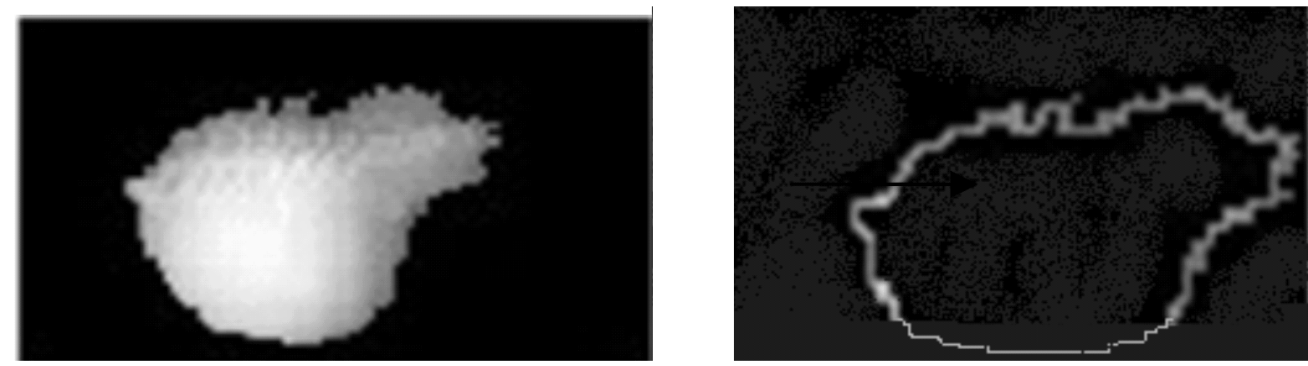

Fig. 2. Selection of 2D-curve, cell contour using MathCAD blocks.

Table 1. Average values of fractal dimension of magnetically labelled yeast cells obtained by mechanical mixing

\begin{tabular}{||c|c|c||}
\hline Type of mixing & \multicolumn{2}{|c|}{ Mechanical mixing } \\
\hline \multirow{2}{*}{$\begin{array}{c}\text { Average value of } \\
\text { fractal dimension }\end{array}$} & $10 \mathrm{~min}$ & $30 \mathrm{~min}$ \\
\cline { 2 - 3 } & $\mathbf{1 . 1 2 7 \pm 0 . 0 0 3}$ & $1.135 \pm 0.003$ \\
\hline
\end{tabular}

The program block to determine the fractal dimension of the cell contour includes plotting the dependence of the logarithm of the square cells number required to cover the cell contour on the logarithm of the size of such a cell. The line graph of such a dependence serves as a confirmation of fractal-like structure of the cell contour at appropriate scales (Fig. 2) [16].

The formula for calculating the fractal dimension has the form $[18,19]$ :

$$
D=-\frac{\log N(L)}{\log L}
$$

where $L$ is the cell size to cover the cell contour (Fig. 4), $N(L)$ is the number of cells of size $L$ required to cover the cell contour [18].

Since the yeast cells-nano-labels complexes have a range of values of fractal dimension, it is necessary to calculate the fractal dimension on the dataset. The calculation of fractal dimension is very sensitive to noise in the experimental data, especially to the restrictions on the amount of data [18]. Therefore, we used the sample which included 30 AFM images of yeast biosorbent obtained by multi-vortex MHDM, and the same amount of AFM images of sorbent obtained by mechanical mixing.

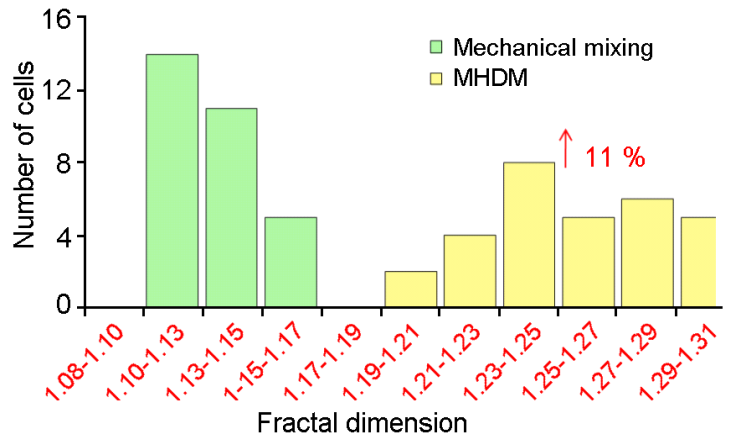

Fig. 3. Fractal dimensions of magnetically labelled yeast cells obtained by different methods of mixing. Mixing time is $30 \mathrm{~min}$.

\section{Results and discussion}

In the present work we demonstrated that the fractal dimension of magnetically labelled biosorbent based on Saccharomyces cerevisiae yeast differs depending on the mixing method of obtaining of magnetically labelled biosorbent. The fractal dimension increases at multi-vortex MHDM in comparison with mechanical mixing (Table 1,2).

The graph of fractal dimensions of magnetically labelled yeast cells obtained by different methods of mixing is presented in Fig. 3. It can be seen from the calculations carried out using MathCAD software with the help of the above-mentioned algorithm that the fractal dimension of the magnetically labelled yeast by MHDM is $11 \%$ higher than that one obtained by mechanical mixing.

It can be seen from Fig. 4 that the stability and sorption capacity of magnetically labelled biosorbent obtained by MHDM are

Table 2. Average values of fractal dimension of magnetically labelled yeast cells obtained by multi-vortex MHDM

\begin{tabular}{||c|c|c|c|c|c|c||}
\hline \hline Type of mixing & \multicolumn{6}{|c|}{ Multi-vortex MHDM } \\
\hline $\begin{array}{l}\text { Average value of } \\
\text { fractal dimension }\end{array}$ & $2 \mathrm{~min}$ & $4 \mathrm{~min}$ & $6 \mathrm{~min}$ & $8 \mathrm{~min}$ & $10 \mathrm{~min}$ & $30 \mathrm{~min}$ \\
\cline { 2 - 7 } & $1.131 \pm 0.009$ & $1.118 \pm+0.009$ & $1.123 \pm+0.007$ & $1.134 \pm+0.007$ & $1.246 \pm+0.006$ & $1.254 \pm 0.006$ \\
\hline
\end{tabular}




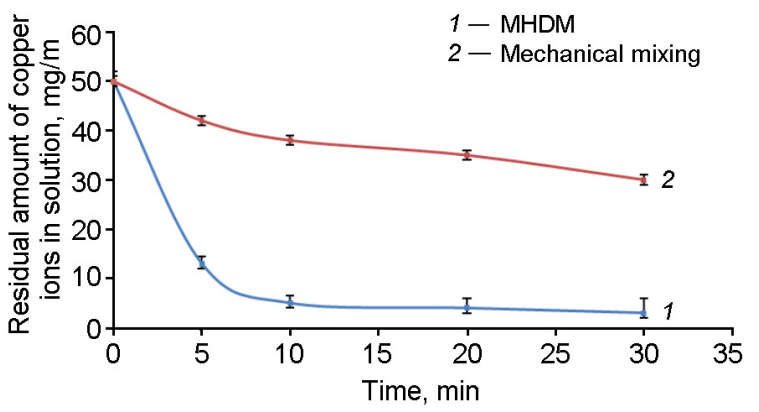

Fig. 4. Sorption characteristics of magnetically labelled biosorbent based on Sac charomyces cerevisiae yeast, obtained by different methods of mixing [11].

higher than those obtained by mechanical mixing.

It is shown in Fig. $1 \mathrm{~b}$ that the magnetic nanoparticles clusters in the cells obtained by mechanical mixing are formed as long chains that are located on the cell surface. The small number of clusters of magnetic nanoparticles (several particles per cell) was observed in the cells obtained by multi-vortex MHDM. This indicates that when using multi-vortex MHDM almost all nano-magnetite particles get inside cells (Fig. 1d), and thus on the cell surface the binding sites for heavy metal ions, particularly copper ions $\mathrm{Cu}^{2+}$, become free. And under mechanical mixing the nano-magnetite localizes on the cell surface (Fig. 1b). The magnetic susceptibility of biosorbent obtained by MHDM is higher than that one obtained by mechanical mixing at the same number of magnetic nano-labels.

Also the magnetic susceptibility of biosorbents obtained by MHDM at $2,4,6,8,10,30 \mathrm{~min}$ was also measured and calculated.

We found the dependence of the fractal dimension and magnetic susceptibility on the time of obtaining of biosorbent by MHDM.

For convenience of comparison of the dynamics of these two parameters, we introduced the following characteristics:

$$
\frac{D-\min (D)}{\max (D)-\min (D)}, \frac{\chi-\min (\chi)}{\max (\chi)-\min (\chi)},
$$

where $D$ - value of fractal dimension; $\chi-$ value magnetic susceptibility, $\max (\chi), \min (\chi)$ - maximum and minimum values magnetic susceptibility of magnetically labeled biosorbent, $\max (D), \min (D)$ - maximum and minimum values of fractal dimension of magnetically labeled biosorbent.

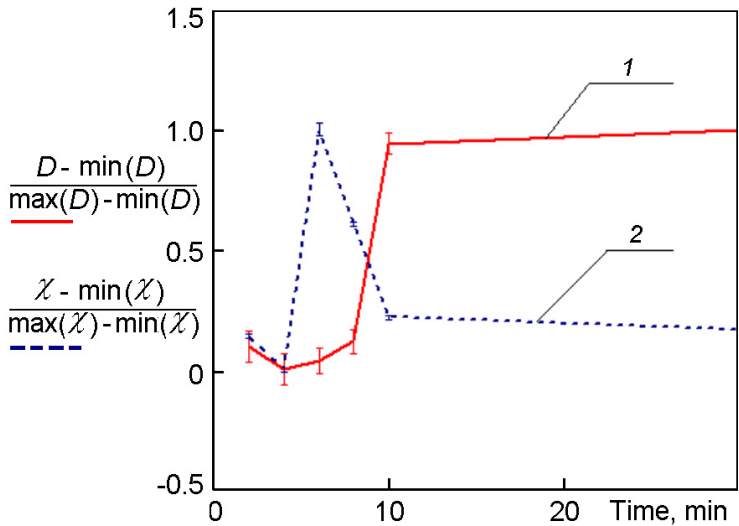

Fig. 5. Dependence of the fractal dimension (curve 1) and magnetic susceptibility (curve 2) on the time of obtaining of biosorbent by multi-vortex MHDM.

We can see from Fig. 5 that both the magnetic susceptibility and fractal dimension reach their saturation values at the same time of the obtaining of magnetically labelled biosorbent $-10 \mathrm{~min}$. The structure of the Saccharomyces cerevisiae yeast cells surface changes and the magnetic nanoparticles desorb in solution. It follows from Fig. 5 that after $10 \mathrm{~min}$ the value of the magnetic susceptibility of a biosorbent reduces. Therefore, after $10 \mathrm{~min}$ of mixing it is impossible to obtain a biosorbent based on Saccharomyces cerevisiae yeast which would be stable with respect to the magnetic susceptibility at the obtaining of a magnetically labelled biosorbent by MHDM.

Thus, the magnetic susceptibility and fractal dimension are the criteria of quality assessment of obtained magnetically labelled biosorbent.

\section{Conclusions}

The fractal dimension of magnetically labelled Saccharomyces cerevisiae yeast cells obtained by MHDM and by conventional mechanical mixing was calculated. It is shown that the fractal dimension of magnetically labelled cells obtained by MHDM is $11 \%$ higher than that one obtained by mechanical mixing. The magnetic susceptibility of the modified magnetically labelled biosorbent based on Saccharomyces cerevisiae yeast, obtained by MHDM the yeast suspension with nano-magnetite particles, was studied. It was found that the magnetic susceptibility reaches its maximum value at $6 \mathrm{~min}$ of obtaining of a biosorbent. Therefore, such a magnetically labelled biosorbent is the most stable. It was established that the surface structure and stability of magnetic suscepti- 
bility change with the change of fractal dimension of magnetically labelled biosorbent that is the qualitative characteristics of magnetically labelled biosorbent based on Saccharomyces cerevisiae yeast, obtained by MHDM.

\section{References}

1. B.Volesky, Biosorption and Biosorbents. Biosorption of Heavy Metals, Florida (1990).

2. Y.Madrid, C.Camara, Trends Anal.Chem., 16, 36 (1997).

3. F.Veglio, F.Beolchini, Hydrometallurgy, 44, 316 (1997).

4. G.Winkelmann, R.Winge, NewYork Basel, 12, 259 (1994).

5. V.S.Podgorskij, T.P.Kasatkina, O.G.Lozovaja, Mikrobiol.J., 1, 7 (2004).

6. M.Patzak, Biotechn. Techn., 11, 7 (1997).

7. S.V.Gorobets, O.Yu. Gorobets, O.K.Dvoynenko, Res. Bull. NTUU "KPI", 3, 15 (2010).

8. S.V.Gorobets, Yu.V.Karpenko, L.V.Marynchenko, Bull. Donetsk Nat. Univ., 1 (2010) [in Ukrainian].
9. H.Y.Sung, J.Macromol. Biosci., 12, 43 (2012).

10. P.Qingqing, J. Hazardous Mater., 177, 3 (2010). 11.S.V.Gorobets, T.P.Kasatkina, O.Yu.Gorobets et al., Food Industry, 3 (2004).

12. B.Wolfgang, D.Charles Mackenzie, Cornell University Library http://www.pa.msu.edu/ bauer/cancer/cancer.pdf.

13. R.Dobrescu, C.Vasilescu, L.Ichim, Proc. of the 5th WSEAS Int. Conf. Non-Linear Analysis, Non-Linear Systems and Chaos, Bucharest, Romania, 16 (2006).

14. M.E.Dokukin, N.V.Guz, R.M.Gaikwad et al., Phys. Rev. Lett., 2, 107 (2011).

15. Fractals and Multifractals, ed. by S.V.Bojokina, Scientific Publishing Center, Izhevsk (2001) [in Russian].

16. Introduction to the Theory of Fractals, ed. by A.D.Morozova, Scientific Publishing Center, Izhevsk (2002) [in Russian].

17. http://www.ntmdt.ru

18. T.Vicsek, Fluctuations and Scaling in Biology, Oxford University Press, Oxford (2001).

19. B.Dubuc, J.Quiniou, C.Roques-Carmes at al., Phys.Rev., 7, 39 (1989). 